\title{
Disease and lifestyles perception in public workers who are overweight or obese
}

\author{
Percepción de la enfermedad y estilos de vida en trabajadores públicos con sobrepeso y obesidad \\ María G. Beltrán-Rodríguez ${ }^{a}$, Ana Y. Escudero-Castelán ${ }^{b}$, Alejandra Lima-Quezada ${ }^{c}$, Diana \\ K. Straffon-Olivares ${ }^{d}$, María C. Ricón-Cruz ${ }^{e} \&$ Jesús C. Ruvalcaba-Ledezma $^{f}$.
}

\begin{abstract}
:
The development of well-being in the population becomes an important aspect for health due to the repercussions that can bring to their lives, currently obesity is a public health problem that is characterized by being a chronic disease, caused by various factors ranging from genetic, metabolic or socio-cultural problems. In this regard it has been mentioned that this imbalance with a negative tend between food intake and caloric expenditure, since, there is an increase in the first and a decrease in the second, which causes adipose tissue accumulates and body weight is raised, it has been reported that the appearance of obesity in early stages of development (childhood/adolescence), increases the possibility of prolonging it until adulthood. The condition of obesity can be permanent by various aspects previously mentioned, such as physical discomfort, anxiety, sadness, feelings of guilt, frustration, reproaches towards himself or his environment, in the regard, it could be due to the ideal of beauty that prevails today-thinness-so when compared to this ideal causes biological, physical, physiological and social changes the threaten the quality of life. Due to this, the objective of the present investigation was to know the perception that workers and workers possess the Sistema Estatal para el Desarrollo Integral de la Familia (SEDIF), with overweight and obesity, regarding their lifestyles and the presence of the disease in their life.
\end{abstract}

\section{Keywords:}

Trajectory, perception, overweight, obesity

\section{Resumen:}

El desarrollo del bienestar en la población se vuelve un aspecto importante para la salud debido a las repercusiones que pueden traer a la vida de los mismos, actualmente la obesidad es un problema de salud pública que se caracteriza por ser enfermedad crónica, causada por diversos factores que van desde problemas genéticos, metabólicos o socioculturales, al respecto se ha referido que ese desequilibrio con tendencia negativa entre la ingesta alimentaria y el gasto calórico, ya que, se observa incremento en la primera y una disminución en la segunda, lo que origina que el tejido adiposo se acumule y se eleve el peso corporal se ha referido que la aparición de obesidad en etapas tempranas del desarrollo (infancia/adolescencia), aumenta la posibilidad de prolongarla hasta la adultez. La comorbilidad de la obesidad atenta contra la salud física y mental de quien la padece. Bajo este razonamiento, la condición de obesidad puede verse permeada por diversos aspectos previamente mencionados, como malestar físico, ansiedad, tristeza, sentimientos de culpa, frustración, reproches hacia sí mismo o su entorno, al respecto, podría ser por el ideal de belleza que prevalece en la actualidad - la delgadez- así al compararse con dicho ideal provoca alteraciones biológicas, físicas, psicológicas y sociales que atentan con la calidad de vida. Debido a esto el objetivo de la presente investigación fue conocer la percepción que poseen personas trabajadores y trabajadoras del Sistema Estatal para el Desarrollo Integral de la Familia (SEDIF), con sobrepeso y obesidad, con respecto a sus estilos de vida y la presencia de esta enfermedad en su vida.

\section{Palabras Clave:}

Trayectoria, percepción, sobrepeso, obesidad

\footnotetext{
${ }^{a}$ Universidad Autónoma del Estado de Hidalgo, Instituto de Ciencias de la Salud, https://orcid.org/0000-0003-2709-2980, Email: lupitabr90@ hotmail.com ${ }^{\mathrm{b}}$ Universidad Autónoma del Estado de Hidalgo, Instituto de Ciencias de la Salud, https://orcid.org/0000-0001-6466-1578, Email: yare.h2693@ gmaill.com ${ }^{\mathrm{c}}$ Universidad Autónoma del Estado de Hidalgo, Instituto de Ciencias de la Salud, https://orcid.org/0000-0001-8768-7340, Email: ale.limaq28@ gmail.com d Autor de Correspondencia, Universidad Autónoma del Estado de Hidalgo, Instituto de Ciencias de la Salud, https://orcid.org/0000-0002-5727-0111, Email: karinastraffon94@gmaill.com

${ }^{e}$ Universidad Autónoma del Estado de Hidalgo, Instituto de Ciencias de la Salud, https://orcid.org/0000-0003-4966-8549, Email: carmenc278@ @otmail.com

${ }^{\mathrm{f}}$ Universidad Autónoma del Estado de Hidalgo, Instituto de Ciencias de la Salud, https://orcid.org/0000-0002-5593-3946, Email: dcspjcarlos@ gmail.com
} 


\section{INTRODUCCIÓN}

Obesity is a chronic disease, caused by various factors ranging from genetic, metabolic or socio-cultural problems, in this regard it has been mentioned that this imbalance with a negative trend between food intake and caloric expenditure since there is an increase in the first (over-intake of food rich in carbohydrates and fat ) and a decrease in the second(lack of physical activity and sedentarism, which causes Adipose tissue to accumulate and body weight to increase.

The World Health Organization (OMS,2019) defines overweight and obesity as an abnormal or excessive increase of fat that presents a risk to health, the body mass index (BMI) is a simple indicator that relates height and weight commonly used to identify overweight and obesity in an adult population. It is calculated by dividing a person's weight in kilograms by the square of his or her height in meters $(\mathrm{kg} / \mathrm{m} 2)$. For the adult population, WHO defines overweight obesity as follows, overweight is a BMI higher than or equal to 25 , and obesity is a BMI higher than or equal to 30. BMI provides the most useful population-level measure of overweight and obesity as it is the same for both sexes and all ages of adults. However, it should be considered a rough guide because it may not correspond to the same degree of fatness in different individuals.

The World Health Organization (OMS, 2019) refers that since 1975, obesity has tripled throughout the world. In 2016 over 1900 million people aged 18 or over were overweight, of which more than 650 million were obese, likewise $39 \%$ of the adult population aged 18 and over were overweight, and the $13 \%$ were obese, most of the world's population live in countries where overweight and obesity take a more significant death toll than underweight.

In Mexico, the 2016 health-and -nutrition survey refers that for the adult population aged 20 and over, there is combined national prevalence of obesity and overweight of $71.2 \%$ in 2012 y $72.5 \%$ (INSP, 2016). What is relevant is that the obesity comorbidity endangers the physical and mental health of those who suffer it, for example, it impacts on the quality and expectancy of life, it has been estimated that per 15 extra kilograms of body weight there is in an increase of $30 \%$ of having a premature death. It increases the risk of developing chronic diseases like diabetes, blood pressure, cardiovascular, among others, and, subsequently increasing the burden of disease, in addition, there are social determinants that may influence the development of overweight and obesity such as education, sex, poverty, place of residence among others. In this regard education is inversely associated with overweight and obesity, on the contrary wealth us directly associated with overweight and obesity, likewise, overweight at early ages is higher in men than in women and obesity is more frequent in women and higher in urban cities due to the growing consumption of "fast food" or "takeout", about one third of consumed calories due to these containing more calories, sutured fats, cholesterol, and less fiber than home-cooked meals.

On the other hand, the obesity condition might be permeated by various aspects above mentioned such as physical discomfort, anxiety, sadness, guilt feelings, frustration, selfblame, in that regard it might be caused by the ideal conception of beauty that prevails today, thinness, therefore when compared to this ideal causes biological physical and social alterations that diminish the quality of life.
Population with overweight or obesity may experience asocial conducts self-esteem problems, body image, and these may lead to an increase in the food intake aggravating or keeping obesity and overweight.

Lifestyles are defined as socials processes, traditions, habits, behaviors of individuals, and groups of the population that lead to satisfying human needs to reach well-being and life. They are determined by risk factors and protective factors for well-being so they should be seen as a dynamic process that is not only composed of actions or individual behaviors but also of social nature actions

The perception of the individual's state of health as body and weight image, expectations, cognitions, and emotions may impact on the lifestyle, which can promote or injure health, according to the theoretical models on behavior modification Perceiving at risk of becoming ill favors the taking of preventive actions.

According to Darlow (2012) Some studies have tried to identify the association between individual perception of body weight and image, with some sociodemographic variables and with the perceived risk of developing noncommunicable diseases, in some studies with the adult population the relationship between the perception of being overweight or obese and the perception of being at risk of developing diabetes and cardiovascular diseases, likewise, being obese is perceived as a serious condition that puts health at risk.

It is considered that an adequate perception of body weight results in a higher probability of identifying potential health risks and, consequently, actions for its prevention or treatment are achieved. Knowing the population's perception of their body weight, obesity, and the probability of developing it in the short term provide useful information to direct health strategies (Royo, 2013).

The objective of the present investigation was to know the perception that workers and workers of the State System for the Integral Development of the Family (SEDIF) have, with overweight and obesity, with regard to their lifestyles and the presence of this disease in their lifetime.

\section{METHOD}

Through ethnography, it aims to analyze the participants through observation and semi-structured interviews to understand their social behavior associated with a chronic degenerative disease such as obesity. It also seeks to try to understand their way of life and their work environment to identify risk factors associated with obesity; in other words, try to understand their reality. Addressing this project from ethnography will lead to understanding the personal issues of the participants (Angrosino, 2012).

Instruments to carry out this research, informed consent was used explaining to the participants the ethical guidelines to be fulfilled when participating in the study. A questionnaire was applied to evaluate the feeding behavior where through 17 questions that covered aspects of the eating habits that the participants possess. Finally, a semi-structured interview was applied where six main areas of disease perception, health status, eating habits, lifestyles, body image, and social perception (support networks) were addressed. 


\section{RESULTS}

Below is the information of the six interviews conducted with 3 male and 3 female workers, describing their age, body mass index, nutritional diagnosis data, placed within the State System for the Integral Development of the Family (SEDIF), family structure through their respective family tree and the analysis of the categorizations found within their interviews through the networks generated with the Atlas.ti program.

Interview number one was conducted with a 46-year-old woman with a BMI of 26.89 , so her nutritional diagnosis is overweight. The occupation of the interviewee is the head of the office of the sub-directorate of food programs. Her family structure is made up of her daughter and her partner (Figure 1). During his interview, categories were found, such as negative personal perception, low self-esteem, inactivity, among others (Figure 2).

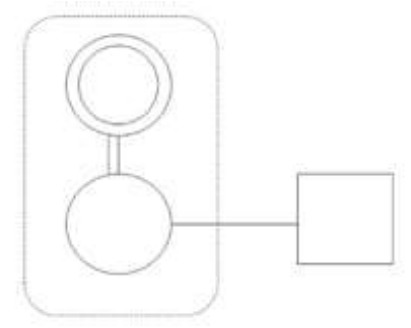

Figure 1. Familiogram of the first line of the interview 1.

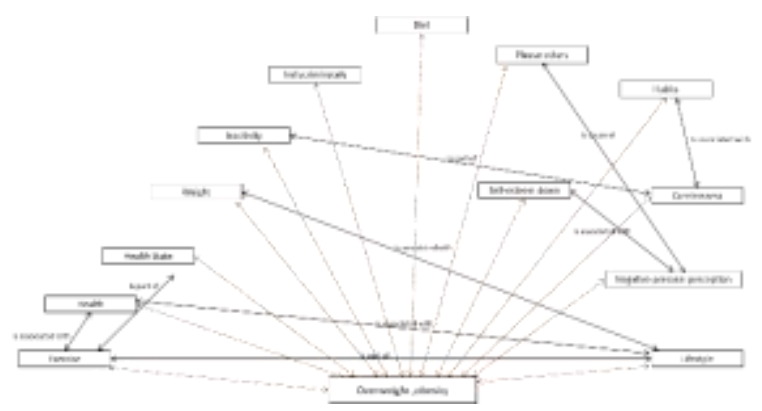

Figure 2. Atlas ti analysis of the interview 1.

Interview number two was conducted with a 56-year-old woman with a BMI of 31.77 so that her nutritional diagnosis is of grade 1 obesity. The interviewee's occupation is Head of the Office of the Department of Supervision and Nutrition Quality (Secretariat). Her family structure is made up of her husband and daughter (Figure 3). During their interview, categories such as feeding were the first problem for the overweight, social problem, not health, among others (Figure 4).

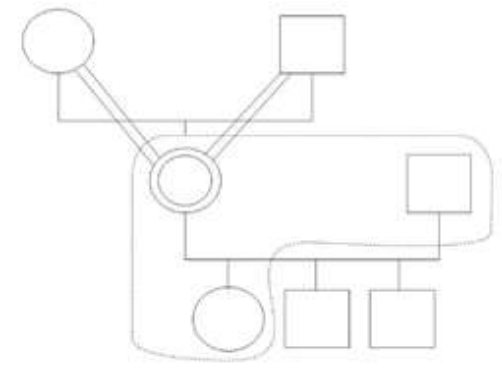

Figure 3. Familiogram of the first line of the interview 2.

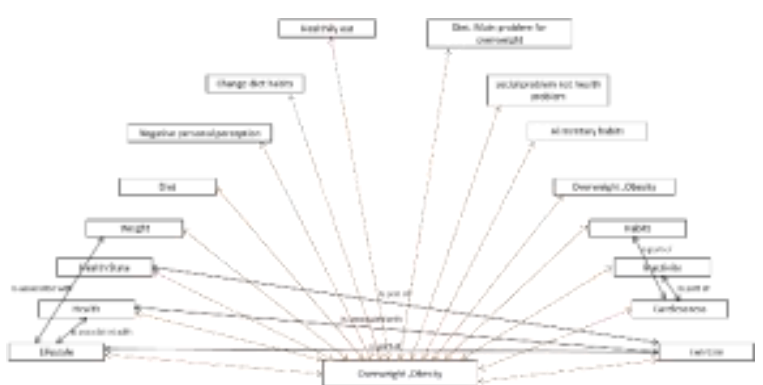

Figure 4. Atlas ti analysis of interview 2.

Interview number three was conducted to a 33-year-old man with a BMI of 38.96 so that his nutritional diagnosis is of grade 2 obesity. The interviewee's occupation is a Specialized Technician of the Information Area of the Department of Supervision and Nutrition Quality. His family structure is made up of his wife and four children (Figure 5). During his interview, categories such as health deterioration, laziness, thick bones, among others, were found (Figure 6).

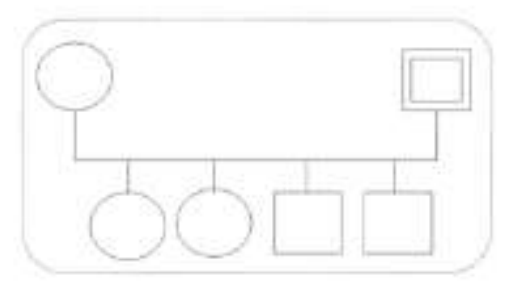

Figure 5. Familiogram of the first line of the interview 3.

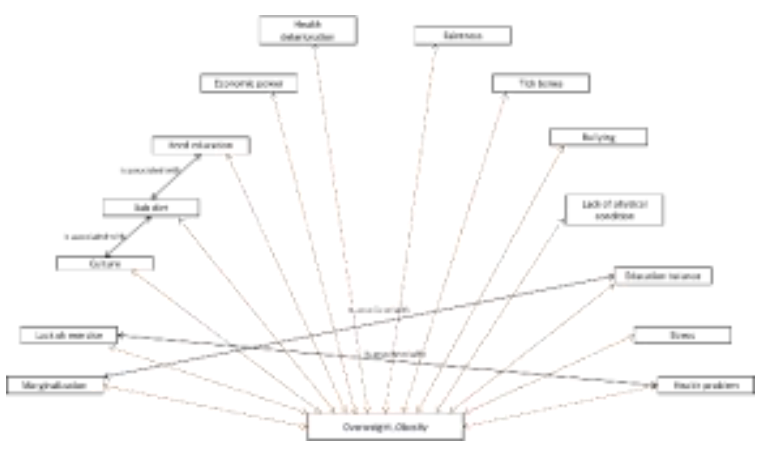

Figure 6. Atlas ti analysis of interview 3.

Interview number four was conducted to a 43-year-old woman with a BMI of 25.56, with which her nutritional diagnosis is overweight. The occupation of the interviewee is Head of the Office of the Supervision Area of the Deputy Directorate of Supervision and Nutrition Quality. Her family structure is made up of her husband and two daughters (Figure 7). During 
his interview, categories such as poor diet, fatigue, among others were found (Figure 8)

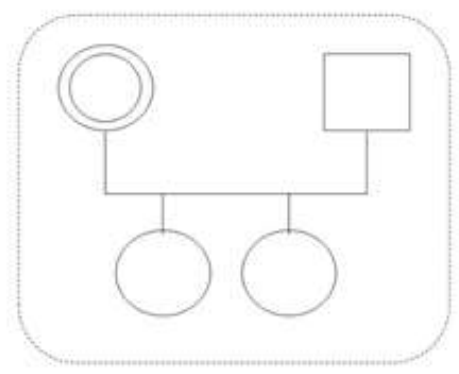

Figure 7. Familiogram of the first line of the interview 4.

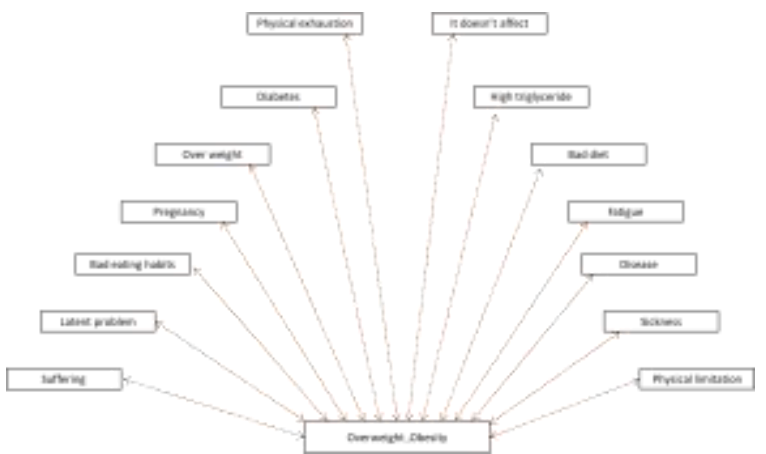

Figure 8. Atlas ti analysis of interview 4.

Interview number five was carried out on a 39-year-old man with a BMI of 30.14, with which his nutritional diagnosis is of grade 1 obesity. The interviewee's occupation is a Specialized Technician of the Information Area of the Department of Supervision and Nutritional Quality. His family structure is made up of his father and brother, although he lives alone (Figure 9). During his interview, categories such as poor diet, headache, among others, were found (Figure 10).

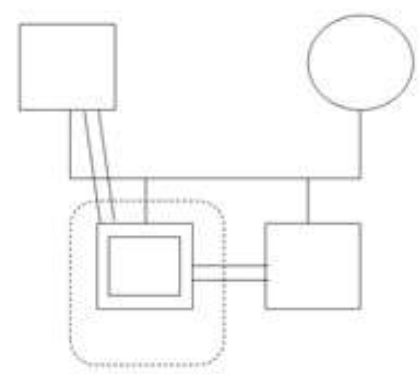

Figure 9. Familiogram of the first line of the interview 5.

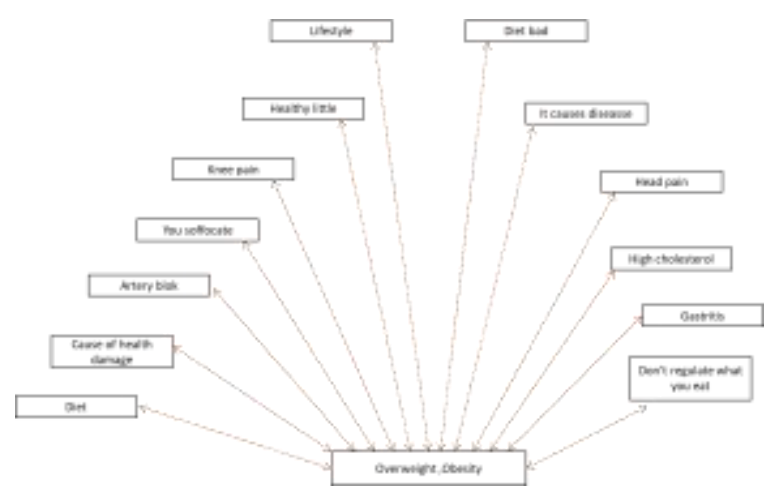

Figure 10. Atlas ti analysis of the interview 5.

Interview number six was carried out on a 50-year-old man with a BMI of 30.31, with which his nutritional diagnosis is grade 1 obesity. The interviewee's occupation is Supervisor of Food Programs. His family structure is made up of his brothers (Figure 11). During his interview, categories such as poor diet, headache, among others, were found (Figure 12).

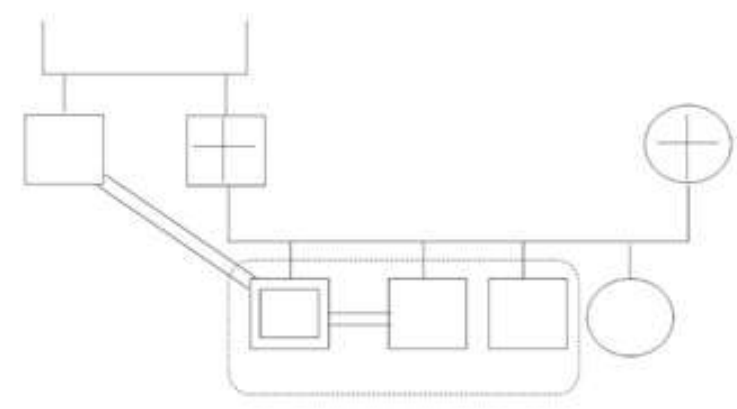

Figure 11. Familiogram of the first line of the interview 6.

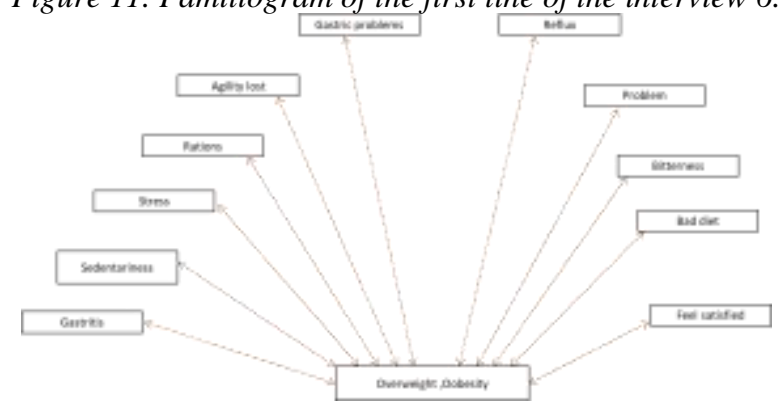

Figure 12. Atlas analysis of interview 6.

When analyzing the interviews, categorizations were found such as diet, problem, illness, causing illness, weight loss, physical fatigue, headache, losing agility, lack of knowledge, sedentary lifestyle, stress, marginalization, weight, medical conditions, health deterioration, no discrimination, suffering, gastric problems, health status, feeling satisfied, diabetes, among others (Figure 13). Four main categories were found within the interviews, which are obesity and overweight, disease perception, eating habits, and personal perception. 


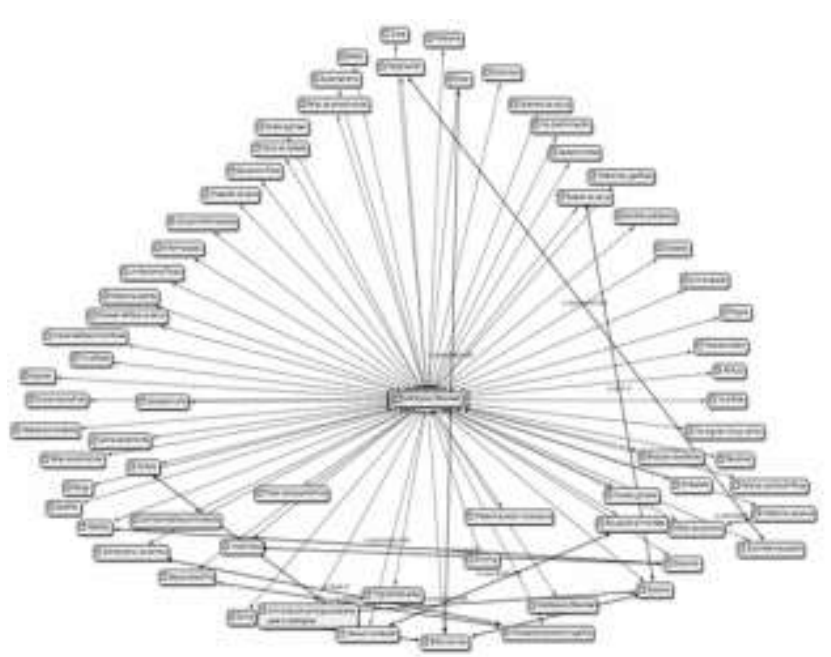

Figure 13. Atlas analysis of all interviews.

Regarding the responses of the sample in the questionnaire to assess the feeding behavior, it was found that regarding the nutritional labels of the products they choose to consume, most participants report not reading due to laziness representing $35.3 \%$ and $29.5 \%$ mention that they do read them and understand them which influences in the same way for the choice of the product or food they consume as seen in Figure 14.

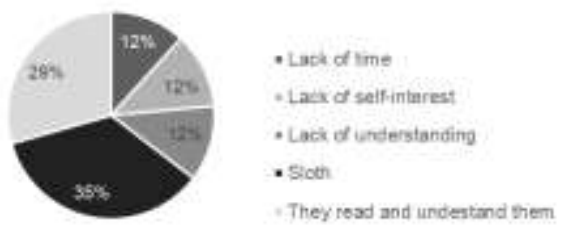

Figure 14. Reasons why participants do not read nutritional labels.

Participants were questioned about who is the person who prepares the food they regularly consume, $52.9 \%$ report that they prepare them themselves, $23.5 \%$ buy them prepared, $17.6 \%$ are prepared by a family member and $5.9 \%$ are prepared by the person which helps in the house as can be seen in Figure 15.

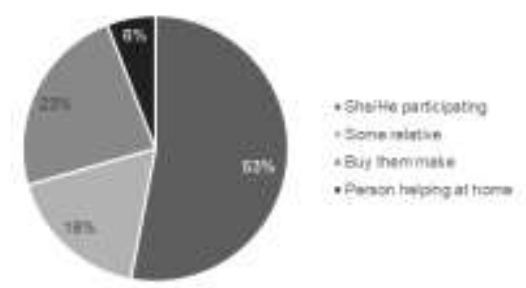

Figure 15. A person who prepares food more frequently.

Figure 16 shows what the participants usually drink most of the day; $70.6 \%$ refer to drinking natural water.

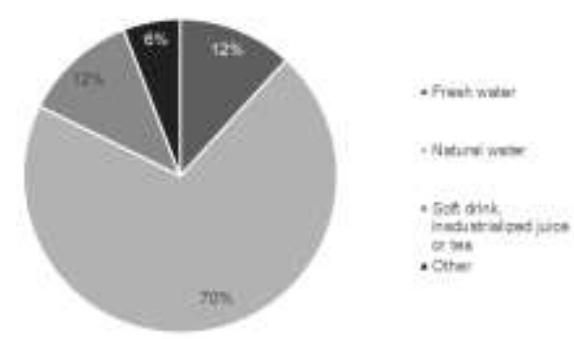

Figure 16. Drinks that are consumed most frequently during the day.

Figure 17 shows what they usually eat between meals; $41.2 \%$ eat fruits or vegetables, followed by $23.5 \%$ who eat candies.

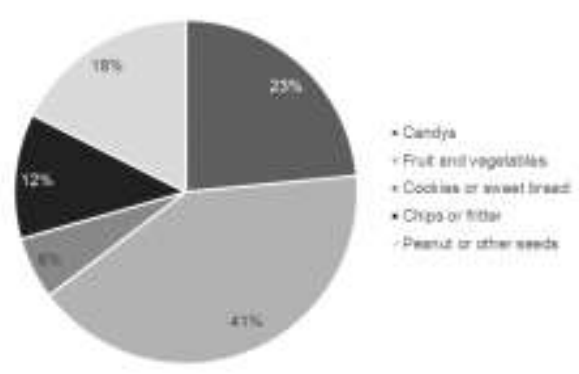

Figure 17. Foods consumed between meals.

Participants were asked how often they eat out, and 52.9\% mention that they do it once or twice a week (Figure 18).

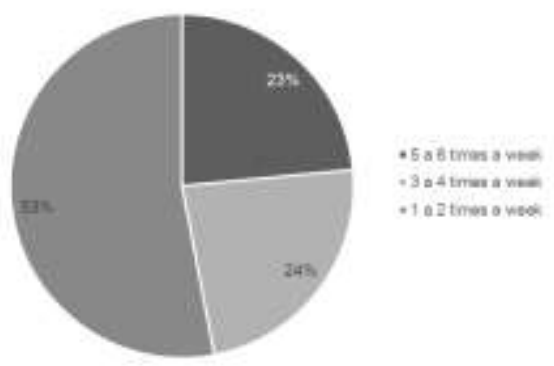

Figure 18. Frequency of meals away from home.

Participants were asked how often they overeat, and $47.1 \%$ report that once to twice a week (Figure 19). 


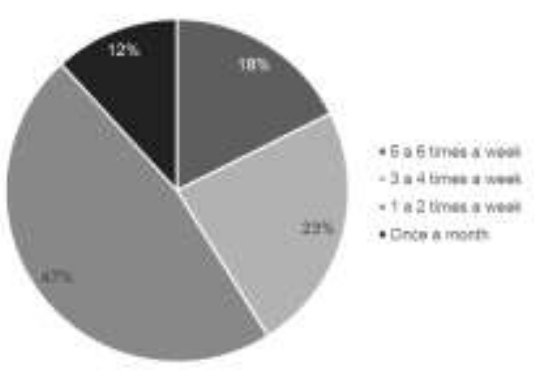

Figura 19. Frecuencia de comidas en exceso.

\section{DISCUSSION}

Overweight and obesity represent serious public health problems that require immediate attention. It is known to be a disease triggered mainly by lifestyles, such as lack of exercise, poor diet, and/or sedentary lifestyle. Currently, the globalized world demands a higher labor demand, which implies that the working day of a worker is more extended, considerably affecting their eating or sleeping habits, this coupled with emotional disturbances such as stress, anxiety, or depression. According to the Precautionary Adoption Process (PAP) model (Weinstein \& Sandman, 2002 in Florez, 2007) which describes the process of acquiring healthy behavior in seven stages: stage 1: the person does not know the importance of healthy behavior $\mathrm{x}$, stage 2 : the person has no interest in incorporating healthy behavior, cover 3 : the person is interested in healthy behavior, but still does not decide to put it into practice, stage 4: the person decides not to act, stage 5: the person has already decided to act, but has not yet begun to do so, stage 6: the person has incorporated healthy behavior into his life, stage 7: he is prolonged in maintaining the execution of healthy behavior.

The interviewees are in the intermediate levels, which refer to decision-making, since they are among the idea of being interested in healthy behavior, in this case, they have identified healthy eating and physical activity, however, they have not decided to put it into practice and in the decision to act, but have not yet begun to do so.

Motivation is a construct that has been referenced as a variable dependent on availability to change, according to the Health Belief Model (MCS), motivation is proposed as an antecedent to healthy action, which refers to availability of the person to get involved in matters related to health, or take into account health within their personal goals (Florez, 2007). In this sense, the participants of this study, do not show a motivation to health, in relation to being overweight or obese, since they do not visualize this as a health problem in their life.

Finally, returning to the Theory of Self-efficacy (Bandura, 1977 in Florez, 2007) which defines the expectation of selfefficacy as the conviction that a behavior can be satisfactorily executed to generate a result, participants report that their overweight or complexion is attributable to their age, to factors such as having children and even to their composition derived from previous activities, since, although they identify behaviors that are favorable for their state of health, they do not consider that modifying their habits will be able to avoid being overweight or obese.
The present study allowed us to investigate the trajectory of the disease with overweight or obese workers of the System for the Integral Development of the Family of Hidalgo (SEDIF). Mainly, it was intended to address the way in which they perceived the disease and how it has affected their lives, in addition to investigating how their work influences this condition. The work was formed by two phases.

During the general evaluation of eating habits and body mass index in the workers of the System for the Integral Development of the Family of Hidalgo (SEDIF), in which 17 men and women participated, it was found that most of the participants report having habits healthy as the consumption of fruits or vegetables and not consume alcoholic drinks or sugary foods, however, in the same way, they refer to being more careful of their food and health. However, in the evaluation of the body mass index, the participants presented diagnoses of overweight or obesity, confirming the participants' beliefs about the care of their diet and health. Another critical finding was that they perceive that they need to take care of their food and health, most reported that they need to have the motivation and personal commitment, while others need time and/or money.

\section{CONCLUSION}

The main findings of these interviews focused on the identification of overweight and obesity as problematic for the interviewees since they recognize that it can affect their state of health. However, at the time of the interview, they do not consider it a problem for them, although they begin to identify physical symptoms associated with the condition. In the same way, they recognize the importance of working care aspects such as better food, more time to take care of themselves and exercise. Although informants recognize what they need to work on, one more variable was identified that greatly influences health care and their social life, self-esteem.

It turned out that this variable is associated with the perception they have about themselves, each informant described it differently, some accept themselves as they are and others recognize that they do not like their person in general. Likewise, self-esteem, according to the literature, is closely related to the social field. It implies, in some way the way in which the person relates to the others, in terms of the description of the participants, are perceived socially adapted and that their physical condition has not caused them complicated social situations, which is favorable for them, since they have the ability to develop positive support networks that allow them to face adversities in the future, such as health complications or take actions in the present to take care of your health.

\section{REFERENCES}

Angrosino, M. (2012). Etnografía y observación participante en investigación cualitativa. Ediciones Morata.

Darlow. (2008). Weight perceptions and perceived risk for diabetes and heart disease among overweight and obese women, Suffolk County, New York, Prev Chronic Dis., 365-381. 
Darlow. (2008). Weight perceptions and perceived risk for diabetes and heart disease among overweight and obese women, Suffolk County, New York, Prev Chronic Dis., $365-381$

Dávila, J., González, J., \& Barrera, A. (2015). Panorama de la obesidad en México. Revista Médica del Instituto Mexicano del Seguro Social. 53(2). 240-249.

Dávila, J., González, J., \& Barrera, A. (2015). Panorama de la obesidad en México. Revista Médica del Instituto Mexicano del Seguro Social. 53(2). 240-249.

Flórez, L. (2007). Psicología social de la salud. Promoción y prevención. Bogotá, Colombia: Manual Moderno.

Harris. (2008). BMI-based body size guides for women and men: development and validation of a novel pictorial method to assess weight-related concepts. Int J Obes. , 336-342.

Instituto Nacional de Salud Pública (INSP). (2016). ENSANUT. Cuernavaca: INSP

Macías, A. I., Gordillo, L. G., \& Camacho, E. J. (2012). Hábitos alimentarios de niños en edad escolar y el papel de la educación para la salud. Revista Chilena de Nutrición. 39(3). 40-43.

Martínez-Munguía, C. \& Navarro-Contreras, G. (2014) Factores psicológicos, sociales y culturales del sobrepeso y la obesidad infantil y juvenil en México. Revista Médica del Instituto del Seguro Social. 52(1). 94-101.

Mercado, M. (2016). Calidad de vida en personas obesas. Revista Científica y Profesional de la Asociación Latinoamericana para la Formación y la Enseñanza de la Psicología. 4(11). 88-92.

OMS. (2019). Sobrepeso y Obesidad. Obtenido de Sobrepeso y Obesidad. Recuperado de: https://www.who.int/es/newsroom/fact-sheets/detail/obesity-and-overweight

Royo. (2013). La alimentación y el consumidor. Madrid: Escuela Nacional de Sanidad.

Thompson, J. K., Schaefer, L., \& Menzel, J. E. (2012). Internalization of thin-ideal and muscular-ideal. En T. F. Cash, Encyclopedia of Body Image and Human Appearance (p.p.. 499-504). San Diego, California, E. U.: Academic Press.

Wong de Liu, C. (2017). Estilos de vida. Guatemala: Universidad de San Carlos de Guatemala. 